University of Nebraska - Lincoln

DigitalCommons@University of Nebraska - Lincoln

September 2002

\title{
A REVIEW OF THE GENUS HYLAMORPHA ARROW (COLEOPTERA: SCARABAEIDAE: RUTELINAE: ANOPLOGNATHINI: BRACHYSTERNINA)
}

\author{
Brett C. Ratcliffe \\ University of Nebraska-Lincoln, bratcliffe1@unl.edu \\ Federico Carlos Ocampo \\ University of Nebraska-Lincoln, focampo@unlserve.unl.edu
}

Follow this and additional works at: https://digitalcommons.unl.edu/entomologypapers

Part of the Entomology Commons

Ratcliffe, Brett C. and Ocampo, Federico Carlos, "A REVIEW OF THE GENUS HYLAMORPHA ARROW (COLEOPTERA: SCARABAEIDAE: RUTELINAE: ANOPLOGNATHINI: BRACHYSTERNINA)" (2002). Papers in Entomology. 35.

https://digitalcommons.unl.edu/entomologypapers/35

This Article is brought to you for free and open access by the Museum, University of Nebraska State at DigitalCommons@University of Nebraska - Lincoln. It has been accepted for inclusion in Papers in Entomology by an authorized administrator of DigitalCommons@University of Nebraska - Lincoln. 


\title{
A Review of the Genus Hylamorpha Arrow (Coleoptera: SCARAbaeidae: Rutelinae: ANOPlognathini: Brachysternina)
}

\author{
Brett C. Ratcliffe and Federico C. OCAMPO \\ Systematics Research Collections \\ W-436 Nebraska Hall \\ University of Nebraska \\ Lincoln, NE 68588-0514, U.S.A. \\ bratcliffe1@unl.edu \\ focampo@unlserve.unl.edu
}

\begin{abstract}
The southern Neotropical genus Hylamorpha (Scarabaeidae: Rutelinae: Anoplognathini: Brachysternina) is comprehensively reviewed. Hylamorpha elegans (Burmeister) is now the only species in the genus with $H$. cylindrica Arrow entered into new synonymy. Hylamorpha elegans var. australis Philippi is recognized as an unavailable name. Hylamorpha elegans is established as the type species for the genus, and a neotype for $H$. elegans is designated. Nomenclatural history, descriptions, illustrations, and commentary are included.
\end{abstract}

\section{Resúmen}

El género Hylamorpha (Scarabaeidae: Rutelinae: Anoplognathini: Brachysternina) del sur del Neotrópico es comprensivamente revisado. Hylamorpha elegans (Burmeister) es ahora la única especie del género, $H$. cylindrica Arrow pasa a sinonimia, y $H$. elegans var. australis Philippi es reconocida como nombre no valido. Se establece Hylamorpha elegans como la especie tipo del género y se designa un neotipo para $H$. elegans. Se incluyen la historia nomenclatural,descripciones, ilustraciones y comentarios.

What sort of insects do you rejoice in, where you come from?

Lewis Carroll, Alice in Wonderland

The small South American genus Hylamorpha has been poorly defined since its creation by Arrow in 1899. Most scarab workers knew that $H$. elegans (Burmeister) was an abundant species that had three universally accepted synonyms (Ohaus 1918; Blackwelder 1944; Machatschke 1965, 1972). However, the status and/or placement of $H$. cylindrica Arrow and the so-called $H$. viridis (Burmeister) have been questions waiting to be answered.

In this paper we review the genus by discussing the taxonomic history and stabilizing the nomenclature, designating a type species for the genus and a neotype for $H$. elegans, describing fully $H$. elegans, and delineating its distribution.

This paper is the second in a series of three in this issue of The Coleopterists Bulletin that collectively review and revise the subtribe Brachysternina. The first part is a revision of Brachysternus by Jameson and Smith (2002). The third part is a revision of Aulacopalpus and a phylogenetic analysis, biogeographic analysis, key to genera, and catalog of the Brachysternina by Smith (2002). 


\section{Taxonomic History}

When Arrow (1899) described the genus Hylamorpha, he included in it three species: two new species (H. rufimana and $H$. cylindrica) and the previously described species, Aulacopalpus elegans Burmeister (which he erroneously called A. viridis twice in the same paragraph) that he transferred into Hylamorpha.

Callichloris perelegans Curtis was described in 1845, but Solier (1851) synonymized it with Aulacopalpus elegans. Curtis incorrectly used the generic name Callichloris Burmeister, 1844 for his perelegans; Callichloris is a synonym of the genus Platycoelia Dejean, 1833 (Rutelinae: Anoplognathini).

Sulcipalpus Harold, 1869 was proposed as a replacement name for the genus Aulacopalpus Guérin-Méneville, 1838 [see Smith (2002) revision of Aulacopalpus in this issue], and Aulacopalpus viridis Guérin-Méneville is the type species for the genus Sulcipalpus. Nonfried (1894) described Sulcipalpus subviolaceus, and this species was later synonymized by Arrow (1901) under Hylamorpha elegans. Ohaus (1918), Blackwelder (1944), and Machatschke $(1965,1972)$ all erroneously called Sulcipalpus a synonym of Hylamorpha.

\section{Methods}

The results of this study were based on specimens received on loan from institutions and private collections. The collections and their acronyms (Arnett et al. 1993), including curators and/or collections managers who provided material, are as follows.

AMNH: American Museum of Natural History, New York, NY (Lee Herman, Jr.).

BCRC: $\quad$ Brett C. Ratcliffe Collection, Lincoln, NE.

BMNH: The Natural History Museum (formerly British Museum of Natural History), London, England (Michael Bacchus, Malcolm Kerley).

CASC: $\quad$ California Academy of Sciences, San Francisco, CA (Norman Penny, David Kavanaugh).

CMNC: $\quad$ Canadian Museum of Nature, Ottawa, Canada (Robert Anderson, François Génier).

CMNH: Carnegie Museum of Natural History, Pittsburgh, PA (John Rawlins, Robert Davidson).

CNCI: $\quad$ Canadian National Collection of Insects, Ottawa, Canada (Jean McNamara, Yves Bousquet).

DEIC: Deutsches Entomologisches Institut, Eberswalde, Germany (Lothar Zerche).

FMNH: $\quad$ Field Museum of Natural History, Chicago, IL (Al Newton, Philip Parrillo, Hank Dybas).

FSCA: $\quad$ Florida State Collection of Arthropods, Gainesville, FL (Brenda Beck, Mike Thomas).

HAHC: Henry and Anne Howden Collection, Nepean, Ontario, Canada.

KSUC: Kansas State University Collection, Manhattan, KS (Ralph Charlton).

LACM: Los Angeles County Museum of Natural History, Los Angeles, CA (Roy Snelling).

MLJC: $\quad$ Mary Liz Jameson Collection, Lincoln, NE.

MLPA: $\quad$ Museo de la Plata, La Plata, Argentina (Juan Shnack). 
MLUH: $\quad$ Martin Luther Universität, Halle, Germany (Manfred Dorn). NHMB: Naturhistorisches Museum, Basel, Switzerland (Georg Frey Collection) (Daniel H. Burckhardt).

PVGH: $\quad$ Pedro Vidal Collection, Santiago, Chile.

ROME: $\quad$ Royal Ontario Museum, Toronto, Canada (Doug Currie, Brad Hubley).

SEMC: $\quad$ Snow Entomological Museum, Lawrence, KS (Steve Ashe).

UMRM: $\quad$ W R. Enns Entomology Museum, University of Missouri, Columbia, MO (Robert Sites).

USNM: United States National Museum, Washington, D.C. (Robert Gordon, David Furth Gloria House).

ZMHU: Museum für Naturkunde, Berlin, Germany (Manfred Uhlig, Fritz Hieke, Joachim Schulze, Hella Wendt).

ZSMC: Zoologische Staatssammlung, Munich, Germany (Gerhard Scherer, Max Kuhbander).

The generic and species description were based on the following sequence of characters: length (from apex of clypeus to apex of elytra), color, frons, clypeus, interocular width, antennae, pronotum, scutellum, elytra, pygidium, legs, venter, and parameres.

Geographical localities are arranged by country, province or department, and specific locality. Temporal data are also provided.

\section{Hylamorpha Arrow, 1899}

Hylamorpha Arrow 1899:368.

Type species: Aulacopalpus elegans Burmeister 1844:459, here designated (see discussion below).

Description. Scarabaeidae, Rutelinae, Anoplognathini, Brachysternina. Form: Suboval, wider behind, dorsum convex. Length 11.0-20.0 mm from apex of clypeus to apex of elytra; width 5.5-11.0 mm across elytral humeri. Color dorsally light to dark apple green, sometimes with brown elytra. Head: Surface densely rugopunctate. Frontoclypeal suture distinct. Clypeus with apex broadly rounded, broadly reflexed. Labrum vertically produced with respect to clypeus, with well-defined median tooth, apex broadly rounded. Mentum with anterior edge produced into small tooth that curves into oral cavity. Pronotum: Surface densely punctate to rugopunctate. Base with fringe of dense, moderately long, white setae extending from beneath posterior margin. Elytra: Surface wrinkled and with punctate striae; punctures with scale-like, white setae. Lateral margin membranous from metepimeron to apex. Pygidium: Surface densely rugopunctate, covered by dense, scale-like white setae. Apex at middle with distinct tuft of longer setae. Legs: Protibia tridentate in both sexes, apical spur lacking. Protarsomeres 1-4 each with pair of small spinules on ventral side at apex; protarsomere 5 with distinct, median tooth on ventral side. All claws simple, not split at apex. Unguitractor plate trisetose. Venter: Prosternum lacking keel. Mesometasternal process absent. Propygidium without supraspiracular ridge. Last sternite entire at apex in both sexes, not emarginate.

Diagnosis. The genus Hylamorpha may be distinguished from other genera of the Brachysternina (Aulacopalpus and Brachysternus) by (1) simple tarsal claws (simple or bifurcate in Brachysternus, simple or bifurcate in Aulacopalpus), (2) multisetose unguitractor plates (bisetose in Brachysternus and $\mathrm{Au}$ lacopalpus), (3) fourth protarsomeres with two, small, straight spines (spines curved in Brachysternus or straight or curved in Aulacopalpus), (4) apex of last sternite entire in females (entire in Aulacopalpus, emarginate in Brachys- 
ternus), and (5) white, scale-like elytral setae (hair-like, slender or thick setae in Brachysternus and Aulacopalpus).

Type Species. Machatschke $(1965,1972)$ incorrectly designated Aulacopalpus viridis Burmeister, 1844 (not A. viridis Guérin-Méneville 1838) as the type species of the genus Hylamorpha. Arrow (1899) did not designate a type species when he created Hylamorpha. However, A. viridis Burmeister is not an available name. Burmeister (1844:459) simply redescribed A. viridis Guérin-Meneville, correctly attributing A. viridis to Guérin-Méneville (1838:58). Aulacopalpus viridis Guérin-Méneville remains a valid species in the genus Aulacopalpus [see Smith (2002) revision of Aulacopalpus and Jameson and Smith (2002) revision of Brachysternus, both in this issue, for further discussion].

Machatschke's $(1965,1972)$ view that the A. viridis of Guérin-Méneville is different than the A. viridis of Burmeister was based on an error by Arrow (1899). When Arrow created the genus Hylamorpha, he described two new species (H. rufimana and $H$. cylindrica) and transferred one previously described species (A. elegans Burmeister) into Hylamorpha. Burmeister's (1844) redescription of $A$. viridis Guérin-Méneville matches Guérin-Méneville's original description. Arrow (1899) knew the identity of the true A. viridis and characterized it properly as "... a glabrous insect, clothed beneath with long hair and not decumbent scales, and having the last joint of the maxillary palpus greatly enlarged and channelled along almost its entire length." However, when Arrow erected the genus Hylamorpha for A. elegans, he inadvertently called the species he placed in it A. viridis Burmeister twice and correctly called it $H$. elegans twice! We know he meant $H$. elegans because he stated that " $H$. viridis Burm. is the only species of this genus at present described" and "Aulacopalpus angustus Philippi must be transferred to the genus Brachysternus, with which it agrees in all essential points, having only a superficial likeness to H. ELEGANS" (emphasis ours). Moreover, Arrow's (1899) description for A. elegans matches his generic description for Hylamorpha whereas the description given for $A$. viridis Guérin-Méneville and the redescriptions by Burmeister (1844) and Arrow (1899) of A viridis do not correspond with Arrow's definition of Hylamorpha. And lastly, Arrow (1901) referred only to $H$. elegans (not $H$. viridis) being in the genus Hylamorpha.

Machatschke (1965), apparently recognizing none of this, designated $\mathrm{H}$. viridis Burmeister as the type species of the genus Hylamorpha. Burmeister (1844) properly credited Guérin-Méneville for describing A. viridis, but Arrow (1899) mistakenly attributed $A$. viridis to Burmeister. Machatschke simply continued Arrow's mistake. Machatschke's designation of A. viridis Burmeister as the type species of the genus Hylamorpha is invalid since there is no such species or name.

Accordingly, we designate Aulacopalpus elegans Burmeister as the type species of the genus Hylamorpha. The type species of Hylamorpha is now fixed pursuant to Article 70.3 of the International Code of Zoological Nomenclature (International Commission on Zoological Nomenclature 1999).

\section{Hylamorpha elegans (Burmeister, 1844)}

(Figs. 1-3; see also Fig. 1 in Smith 2002)

Aulacopalpus elegans Burmeister 1844:459. NEOTYPE male at UNSM (Lincoln), labeled "Santiago, Chile, 1915"// BCR and FCO red neotype label; here designated to stabilize and fix the current concept of the name. 


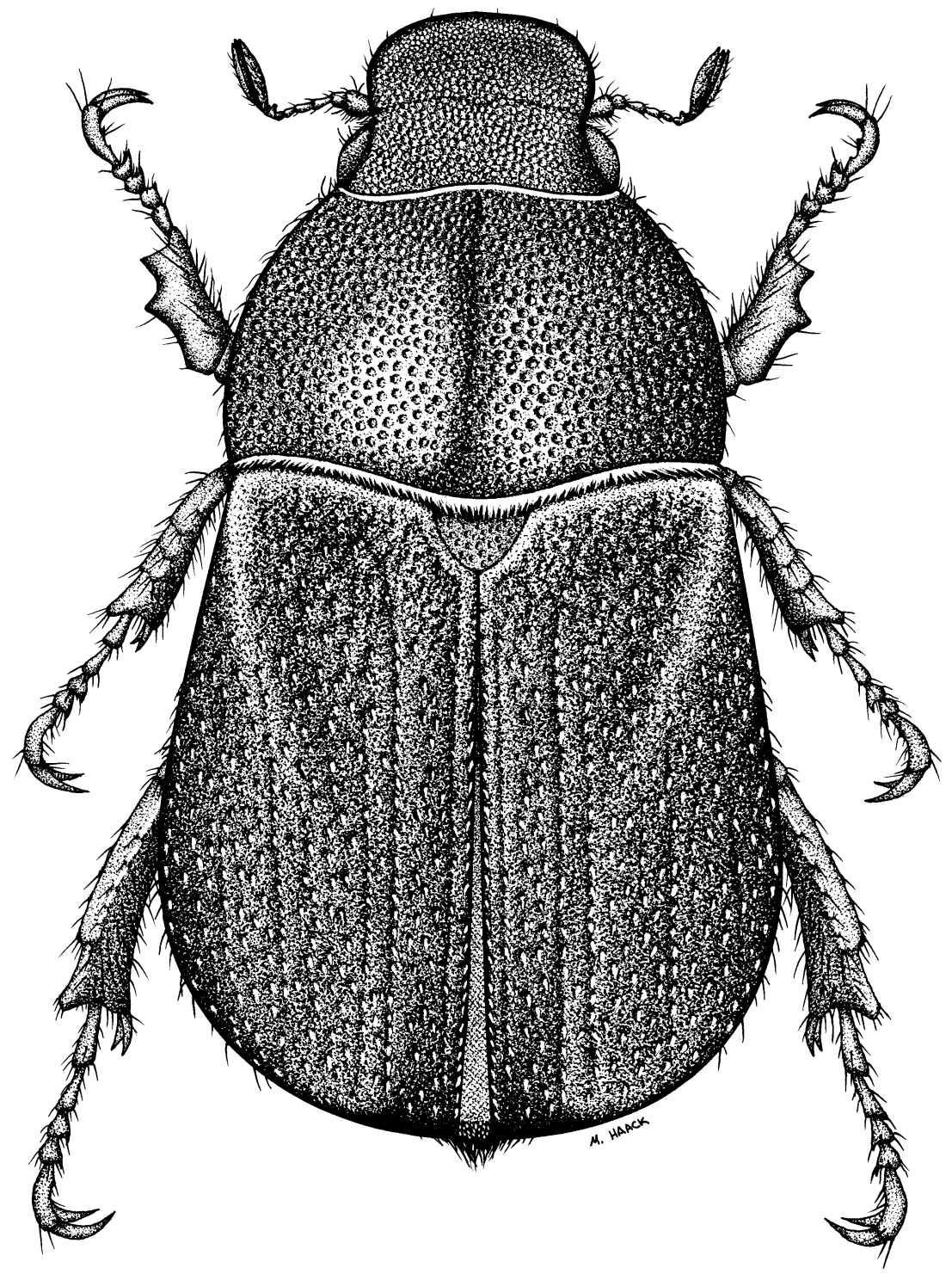

Fig. 1. Dorsal habitus of Hylamorpha elegans (Burmeister).

Callichloris perelegans Curtis 1845:449. LECTOTYPE at BMNH (London), labeled "type" (round label with red border// "Valparaiso" (hand-written)// "Callichloris perelegans Curtis" (hand-written)// BCR lectotype label; here designated to fix and stabilize the current concept of the name. Synonymized by Solier 1851:91.

Aulacopalpus elegans var. australis Philippi 1861:741. Unavailable name. 


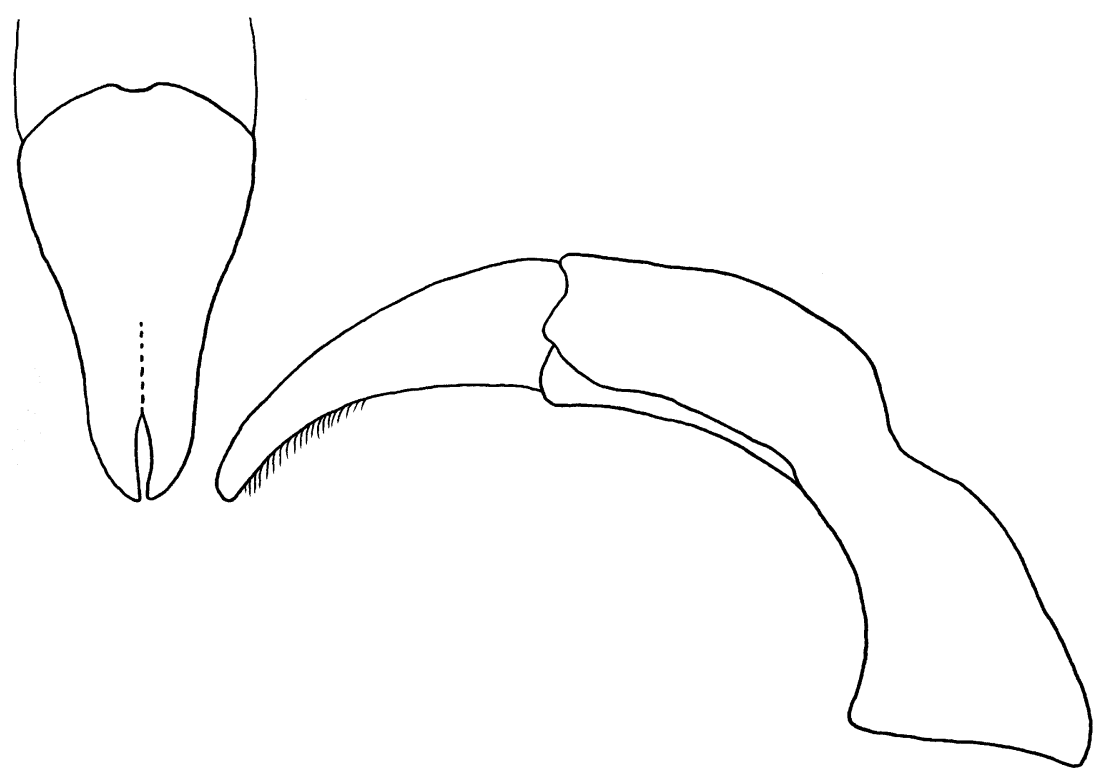

Fig. 2. Male genitalia of $H$. elegans, caudal and lateral views.

Sulcipalpus subviolaceus Nonfried 1894:125. Type not seen. Synonymized by Arrow 1901:401.

Hylamorpha cylindrica Arrow 1899:368. LECTOTYPE at BMNH (London), labeled "syntype" (round label with blue border)// "type" (round label with red border)// "Chile" (hand-written on round label with "44/104" on reverse side//"Hylamorpha cylindrica Arrow Type"// BCR lectotype label; here designated to fix and stabilize the current concept of the name. NEW SYNONYMY.

Hylamorpha rufimana Arrow 1899:368. LECTOTYPE at BMNH (London), labeled "syntype" (round label with blue border// "type" (round label with red border// "Chili 91-54"// "Hylamorpha rufimana Arrow Type" (hand-written)// BCR lectotype label; here designated to fix and stabilize the current concept of the name. Single paralectotype labeled "syntype" (round label with blue border// "Chili 91-54"// BCR paralectotype. Synonymized by Arrow 1901:400.

Description. Length 11.8-18.2 mm; width across humeri 5.8-10.8 mm. Color of head pronotum, and elytra light to dark apple green with metallic silver or bronze or orange (rare) reflection usually present at apex of clypeus, mesad of each eye, on lateral margin of pronotum, and on humeral and apical elytral umbones; occasionally color of head and/or pronotum and/or elytra varies (in part or totally) to light brown or pale greenish yellow; specimens preserved in fluid or killed in gases of certain chemicals may change to cobalt blue, red, orange, or purple. Sternites and pygidium vary from light brown (uncommon) to light or dark olive green (most common). Femora in males usually green (similar to dorsum) or light brown (rare), females with profemora light brown and with meso- and metafemora usually green (similar to dorsum); males with all tibiae green and usually with strong, brassy reflections, especially on meso- and metatibiae; females with protibiae light brown, meso- and metatibiae green and with weak to usually strong brassy or bronzy reflections; tips of protibial teeth black. Thoracic sternites with dense, 


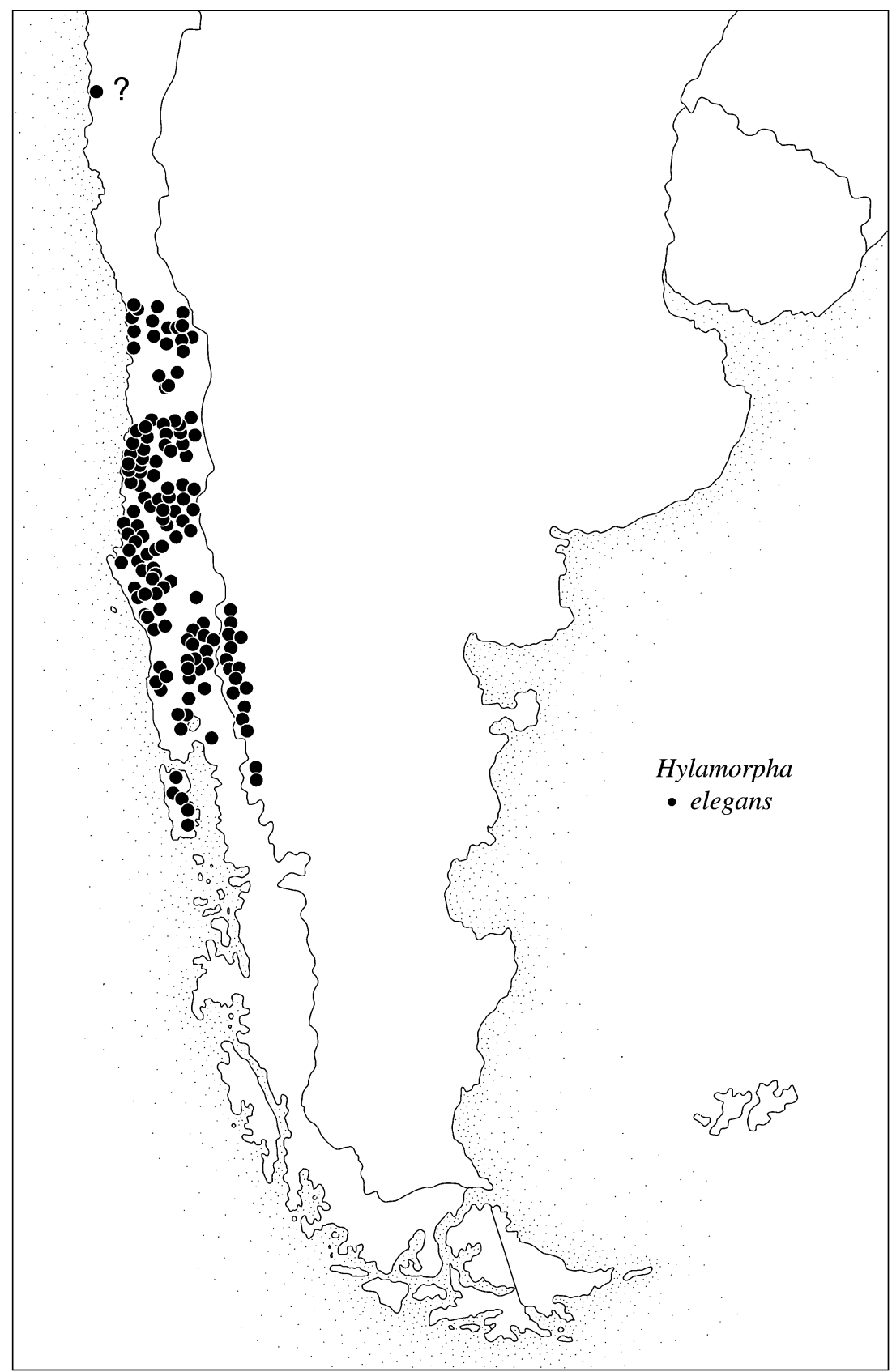

Fig. 3. Locality records for $H$. elegans. 
long, creamy white setae. Abdominal sternites and pygidium with creamy white, scalelike setae; setae short, broad, moderately dense (surface visible between setae) to dense (surface totally obscured); apex of pygidium at center with tuft of white setae. Head: Surface entirely, densely rugopunctate (in smaller, darker specimens) or densely punctate (in larger, lighter specimens); punctures moderately large to large, separated by less than 1 puncture diameter. Frontoclypeal suture finely impressed, arcuate. Clypeus with apex broadly rounded, broadly reflexed. Interocular width equals 5.0-5.7 transverse eye diameters. Antenna with 10 segments, club slender and slightly longer than segments 27 in male, subequal to segments $2-7$ in female. Maxillary palpus with apical segment lanceolate and with most of dorsal surface depressed. Mandibles subtriangular, outer edge arcuate, apex acute to narrowly rounded. Pronotum: Surface densely punctate to rugopunctate similar to that on head except punctures larger. Lateral edge with marginal bead. Sides widest at about middle, strongly contracted from middle to acute apical angle. Basal angle obtusely rounded. Base arcuate, without marginal bead, and with fringe of dense, moderately long, white setae extending from beneath posterior margin. Scutellum broadly subtriangular, apex narrowly rounded; surface densely punctate, punctures small. Elytra: Surface wrinkled and with punctate striae; punctures small, setigerous; setae short, broad. Intervals with sparse, small punctures, some (especially apically) with setae like those of striae. Humeral and apical umbones well-developed. Lateral edge with strong marginal bead. Epimeron broad below humerus, gradually narrowing posteriorly for most of its length, and with sparse, long, white setae extending from just before middle of elytron to anterolateral corners of pygidium. Pygidium: Surface densely and finely rugopunctate but usually obscured by dense setae (often less so in females) and with small tuft of longer setae at apex in center. Disc either side of middle slightly depressed. In lateral view, surface weakly concave to almost flat. Legs: Protibia tridentate, basal tooth slightly removed from others; tibiae wider in females. Protarsomeres 14 each with pair of small, straight spinules at apex on ventral side; segment 5 with small, median tooth on ventral side in basal half, segment subequal in length to segments 1-4 in male, slightly shorter in female (male with first segment 2 times longer than second segment, female with first segment 2.5-3.0 times longer than second segment). Male with one claw larger than other, female with claws subequal in size; apices of all claws simple. Meso- and metatibiae each with short, obliquely transverse carina on external edge just past middle; apices of tibiae weakly expanded and with row of 12-18 small spinules. Venter: Mesometasternal process absent. Sternites 5-6 longer than 1-4, last sternite with apex arcuate and entire in both sexes. Thoracic sternites and posterior edges of femora with moderately dense, long setae; abdominal sternites with dense, elongated, scale-like setae. Parameres: Figure 2.

Neotype. Inasmuch as there has been considerable confusion about the correct identity of the several "species" included in Hylamorpha (as well as the status of the genus itself, i.e., Hylamorpha, Callichloris, Sulcipalpus, or Aulacopalpus), we believe it is essential to fix the type specimen for $H$. elegans. Burmeister (1844) did not designate a type for A. elegans. A type specimen, if such ever existed, was not found by BCR in searches of the Burmeister collection at Martin Luther Universität in Halle, the large collection of the Zoologische Staatssammlung in Munich, the historical collection of the Deutsche Entomologisches Institut in Eberswalde, or the principal collection in Germany at the Museum für Naturkunde in Berlin. In fact, we believe that Burmeister never designated a "typus" because he was referring to the previously existing name of Callichloris elegans in Dejean's catalog (the name is unavailable/nomen nudum because it was never accompanied by a description or reference to one). Burmeister did not believe he was creating a new species but simply referring to a known species listed in a catalog. He became the author of elegans because he was the first to actually describe it. Accordingly, we designate a neotype here.

Burmeister (1844) indicated his specimen was from near Valparaíso, Chile. 
However, we have been unable to locate unbroken male specimens with a label that indicates Valparaíso. Not wanting the neotype to be broken (hence, incomplete), we chose another specimen that agrees with Burmeister's original description and is geographically close to Valparaíso.

Distribution. Hylamorpha elegans is found on both sides of the Andes in central and southern Chile and southwestern Argentina. Its distribution coincides remarkably with the distribution of Nothofagus species (Nothofagaceae) on which it is known to feed.

Locality Records (Fig. 3). 1,930 specimens examined.

ARGENTINA (663). CHUBUT (84): Epuyén, Lago Puelo (6 km N); NEUQUÉN (30): Isla Victoria, Lago Lacar, Parq. Nac. Lanín, Río Quilquihue (San Martín de los Andes), San Martín de los Andes (9 km NE); RÍO NEGRO (549): Bariloche, El Bolsón, Río Villegas (ruta 258).

CHILE (1267). ACONCAGUA (1): No data; ARAUCO (72): Caramávida, Caramávida (20 km W), Contulmo, Pichinahuel; Biobío (131): Bullileo, El Abanico, El Quilleco (30 km E), Santa Bárbara (25 km E); CAUTíN (106): Fundo Chacamo (35 km NW Nueva Imperial), Fundo El Coigue (29 km NW Villarrica), Fundo Las Selvas (750 m NW Nueva Imperial), Loncoche, Loncoche (12.3 km N), Malalcahuello, Nueva Imperial (750 m NW), Pucón, Río Trancura (Villarica), Temuco, Temuco (20 km E), Villarrica, Villa Portales (7 km W); CHILOÉ (28): Ancud, Castro, Chiloé Island (30 km S Ancud), Hueque Trumao (Chiloé Island, 22 km N Quellón), Lago Tepuhueco (40 air km SW Castro); CONCEPCIÓN (47): Fundo Andalién, Fundo Pinares, Hualpencillo, Lirquén, Penco, Punta Hualpén, San Rosendo, Santa Juana; COLCAGUA (2): Peumo; COQUIMBO (2): Ovalle, Parq. Nac. Fray Jorge; CURICÓ (104): El Coigo, Fundo La Montana (6 km E Los Queñes), Las Trancas, Los Niches; LINARES (25): Parral, Tranque de Bullileo; LLANQUIHUE (15): Departamento de Maullín, Ensenada, Lago Chapo; MALLECO (255): Angol, Angol (6 km W), Chanchuco, Cordillera Nahuelbuta, Cordón Las Raíces, Curacautín, Parq. Nac. Nahuelbuta, Perquenco (10 mi. N), Pillín Pilli, Pino Hachado, Termas de Manzanar, Termas de Río Blanco, Vegas Blancas (27 km W Angol), Victoria, Victoria (4 km W), Villa Portales; MAULE (183): Cauquenes (400 m W), Cayurranquil (400 m W Cauquenes), Chovellén, Constitución, El Pantanillo (17 km SE Constitución), Forel, Paso García (23 km NW Cauquenes), Pailahueque, Pelluhue, Río Teno (Teno), Tregualemu; NUULE (79): Alto Tregualemu (20 km SE Chovellén), Cobquecura, Cueva de los Pincheira (Recinto), Curanipe (17.5 km S), Las Trancas (21 km E Recinto), San Carlos (18 $\mathrm{km} \mathrm{E})$, San Carlos (40 km E), San Carlos (50 km E), Recinto, Recinto (4 km $\mathrm{SE}$ ), Recinto (10 km W), Recinto (13 km E); OSORNO (7): Cunco, Osorno, Puyehue, Puyehue (10 km E); SANTIAGO (127): Aculeo, Bucalemu, El Canelo, El Portezuelo (7 km N Santiago), La Herrera, Las Condes, Llolleo, Maipú, Punta Yeso (70 km SE Santiago), Río Blanco, Río Colorado (40 km SE Santiago), Río Peuco (Pilay), Santiago, Santiago (cuesta La Dormida); TALCA (18): Fundo El Radal, Talca (22 mi N), Vilches, Vilches (5 km W), Vilches Alto; VALDIVIA (27): Panguipulli, Pucará, Río Licán (N side Lago Puyehue), Santo Domingo; VALPARAÍSO (16): Algarrobo, Isla Teja, Limache, Valparaíso.

Temporal Distribution. January (217), February (97), March (14), April (3), May (33), September (261), October (13), November (219), December (852). Gutiérrez (1949) reported that $H$. elegans was one of the most common species of scarabs in the Cordillera de Pemehue in a June 1946 expedition, 
and that hundreds of dead specimens were found on the ground in December and January. We saw no museum specimens from June to August.

Remarks. Various catalogs (e.g., Ohaus 1918; Blackwelder 1944; Machatschke 1965,1972 ) have already included the synonymy of all but $H$. cylindrica under $H$. elegans. We concur with these synonymies based upon examination of the types and careful analysis of the original descriptions. Hylamorpha cylindrica (a morphotype that is slightly larger and lighter in color) is conspecific with $H$. elegans and is synonymized here.

Philippi (1861) described Hylamorpha elegans var. australis and explicitly referred to it as a "climatic variety" of $H$. elegans. Accordingly, this name is unavailable because it referred to an infrasubspecific entity described as a variety before 1961 (International Commission on Zoological Nomenclature 1999; Article 45.6.4).

Hylamorpha elegans is variable in size, color, surface sculpturing, amount of setae, and even body shape (somewhat flattened to highly vaulted). Ohaus (1905) correctly noted that darker specimens tended to have more strongly punctate, wrinkled, and setose elytra. Sexual dimorphism is distinct. Males nearly always have green protibia (even if the meso- and metatibiae are brown) whereas females have brown protibiae; males have the first segment of the protarsus a little shorter than in females; males have one claw on all legs larger than the other claw whereas all the claws are subequal in size in females; and males have the antennal club a little longer than in females.

Hylamorpha elegans is often locally abundant. Although frequently associated with Nothofagus forests, it is also found feeding on other native plants and trees and is sometimes an agricultural pest (Pedro Vidal, pers. comm. to BCR, 2000). It occasionally causes severe defoliation of Nothofagus species [principally $N$. antarctica (Forst.), N. betuloides (Mirb.), N. dombeyi (Mirb.), and $N$. obliqua (Mirb.)], and young trees have even been known to be killed by huge numbers of $H$. elegans feeding on them.

(Carrillo and Cerda 1987; Gentili and Gentili 1988; and Veblen et al. 1996).

Glare et al. (1993) reported that the fungus, Beauveria vermiconia (de Hoog and Rao) (Deuteromycotina), was a pathogen of $H$. elegans in Osorno, Chile; in their observations, $20-30 \%$ of a population of late third instar larvae were infected.

During January at Lago Traful (Argentina, Neuquén Province) it is very common to see rainbow trout [Oncorhynchus mykiss (Walbaum)] feeding on adults of $\mathrm{H}$. elegans that fall into the lake water from Nothophagus trees. Hylamorpha elegans is exceedingly abundant on the shores of this lake (and presumably others), and it is a common occurrence to catch trout with their stomachs full of these scarabs (FCO, pers. obs.).

Cartagena (1975) tested success of egg-hatch in different soil types, and found that soils high in sand content favored increased eclosion.

In Chile, H. elegans, along with species of Brachysternus, are referred to as "San Juanes" ("San Juan" for a single specimen); the origin of the name is unknown (P. Vidal, pers. comm., March 2000). They are also called "pololos verdes" (Arias 2000) or also simply "pololos".

\section{Acknowledgments}

We thank Martha Haack (former Scientific Illustrator, University of Nebraska State Museum) for the habitus drawing of $H$. elegans. We are most grateful to the curators and collection managers who made available to us specimens 
for study, and they are listed in the "Methods" section. BCR is especially grateful to Manfred Dorn (Martin Luther Universität, Halle), Manfred Uhlig, Joachim Schulze, and Hella Wendt (Museum für Naturkunde, Berlin), and Jean McNamara (retired, Canadian National Collection of Insects, Ottawa) for logistical support while studying their collections. Pedro Vidal (Universidad Católica de Chile, Santiago) is gratefully acknowledged for loans of specimens as well as valuable information about $H$. elegans in Chile. Harold Gaedike (Deutsches Entomologisches Institut, Eberswalde) is thanked for his clarification on some early German publications. Mary Liz Jameson and Andrew Smith (UNSM, Lincoln) provided invaluable collaboration during our joint revision of the Brachsternina as well as insightful comments on how to improve the manuscript. This project was supported by an NSF/PEET grant (DEB 9712447) to Brett C. Ratcliffe and Mary Liz Jameson and by an NSF Biotic Surveys and Inventory grant (DEB 9870202) to Brett Ratcliffe.

\section{Literature Cited}

Arias, E. T. 2000. Coleopteros de Chile. Fotoneknika, Ltd., Santiago de Chile. 209 pp. Arnett, Jr., R. H., G. A. Samuelson, and G. M. Nishida. 1993. The insect and spider collections of the World. Sandhill Crane Press, Gainesville. 310 pp.

Arrow, G. J. 1899. Notes on the classification of the coleopteran family Rutelidae. Annals and Magazine of Natural History (series 7) 4:363-370.

Arrow, G. J. 1901. Remarks on the secondary sexual differences in rutelid Coleoptera, with descriptions of some new forms. Annals and Magazine of Natural History (series 7) 7:393-401.

Blackwelder, R. E. 1944. Checklist of the coleopterous insects of Mexico, Central America, the West Indies, and South America. Bulletin of the United States National Museum 185:189-341.

Burmeister, H. 1844. Handbuch der Entomologie, vol. 4, part 1. T. C. F. Enslin, Berlin. $585 \mathrm{pp}$.

Carrillo, R., and L. Cerda. 1987. Zoofitófagos en Nothofagus chilenos. Bosque 8:99103.

Cartagena, L. 1975. Crianza y reproduccion de Hylamorpha cilindrica (sic) Arr (Col. Scarabaeidae) en cuatro texturas de suelos. Revista Chilena de Entomologia 9: $165-166$.

Curtis, J. 1845. Descriptions, \&c. of the insects collected by Captain P. P. King, R. N., F. R. S. \& L. S., in the survey of the Straits of Magellan. Transactions of the Linnean Society of London 19:441-475.

Dejean, P. M. F. A. 1833. Catalogue des coléoptères de la collection de M. le Comte Dejean. 2:97-176. Troisième édition, revue, corrigée et augmentée. MéquignonMarvis Père et Fils, Paris.

Gentili, M., and P. Gentili. 1988. Lista comentada de las insectos asociados a las especies sudamericanas del género Nothofagus. Monografías de la Academia Nacional de Ciencias Exactas, Físicas y Naturales (Buenos Aires) No. 4:85-106.

Germain, P. 1905 (1904). Apuntes entomológicos. Anales de la Universidad, Memorias Científicas Literarias 115:449-506.

Glare, T. R., T. A. Jackson, and E. Cisternas A. 1993. Beauveria vermiconia is an entomopathogenic fungus. Mycological Research 97:336-338.

Guérin-Méneville, F. E. 1838. Insectes du voyage de la Favorite. Magasin de Zoologie $8: 1-80$.

Gutiérrez, R. 1949. Notas sobre Scarabaeidae Neotrópicos. Anales de las Sociedad Científica Argentina 148:9-35.

Harold, E. 1869. Scarabaeidae [pp. 979-1346]. In: Catalogus Coleopterorum Hucusque Descriptorum Synonymicus et Systematicus, vol. 4 (M. Gemminger and E. Harold, editors). E. H. Gummi, Monachii.

International Commission on Zoological Nomenclature. 1999. International Code of 
Zoological Nomenclature. International Trust for Zoological Nomenclature, London. 306 pp.

Jameson, M. L., and A. B. T. Smith. 2002. Revision of the South American genus Brachysternus Guérin-Méneville (Coleoptera: Scarabaeidae: Rutelinae: Anoplognathini: Brachysternina). Coleopterists Bulletin 56:321-366.

Machatschke, J. W. 1965. Coleoptera Lamellicornia. Fam. Scarabaeidae. Subfam. Rutelinae. Genera Insectorum Fascicle 199c:1-145.

Machatschke, J. W. 1972. Scarabaeoidea: Melolonthidae Rutelinae. Coleopterorum Catalogus Supplementa Pars 66, Fascicle 1:1-361.

Nonfried, A. F. 1894. Beschreibungen neuer Lamellicornier, Buprestiden und Cerambyciden aus Central- und Süd-Amerika. Entomologische Nachrichten 20:113-142.

Ohaus, F. 1905. Revision der amerikanischen Anoplognathiden (Coleoptera Lamellicornia). Stettiner Entomologische Zeitung 66:120-167.

Ohaus, F. 1918 (1915). Scarabaeidae: Euchirinae, Phaenomerinae, Rutelinae. Coleopterorum Catalogus Pars 66:1-241.

Philippi, F. 1861. Observaciones sobre los lamelicornios de Chile, descritos en la obra del Señor Gay, con descripción de algunas especies nuevas. Anales de la Universidad, República de Chile 18:735-742.

Smith, A. B. T. 2002. Revision of the southern South American endemic genus Aulacopalpus Guérin-Méneville with phylogenetic and biogeographic analyses of the subtribe Brachysternina (Coleoptera: Scarabaeidae: Rutelinae: Anoplognathini). Coleopterists Bulletin 56:379-437.

Solier, A. J. J. 1851. Orden III. Coleópteros [pp. 5-285]. In: Historia Física y Política de Chile, Zoologia, vol. 5 (C. Gay, editor). Privately published, Paris. 564 pp.

Veblen, T. T., C. Donoso, T. Kitzberger, and A. J. Rebertus. 1996. Ecology of southern Chilean and Argentinean Nothofagus forests [pp. 293-353]. In: The ecology and biogeography of nothofagus forests (T. T. Veblen, R. S. Hill, and J. Read, editors). Yale University Press, New Haven. 403 pp.

(Received 11 December 2000; accepted 22 August 2001) 